\title{
Analyzing Controversies in Management and Surveillance of Early-Stage Melanoma
}

\author{
Olga Marushchak (1) · Ezra Hazan · David A. Kriegel
}

Received: June 23, 2020 / Accepted: September 4, 2020 / Published online: September 15, 2020

(C) The Author(s) 2020

\begin{abstract}
The incidence of cutaneous melanoma continues to rise dramatically worldwide, presenting a significant burden to the healthcare system. Despite this, there is still controversy in the guidelines regarding follow-up surveillance for patients with thin melanoma. Since there are no randomized clinical trials to support evidence-based guidelines for follow-up surveillance, dermatologic and oncologic organizations have developed their own recommendations based on expert opinion. However, these recommendations differ widely and
\end{abstract}

Digital Features To view digital features for this article go to https://doi.org/10.6084/m9.figshare.12911654.

O. Marushchak

Clinical Research, Department of Dermatology,

Icahn School of Medicine at Mount Sinai, New York,

NY, USA

E. Hazan · D. A. Kriegel

Division of Dermatologic Surgery, Department of

Dermatology, Icahn School of Medicine at Mount

Sinai, New York, NY, USA

O. Marushchak ( $₫)$

Touro College of Osteopathic Medicine, New York, NY, USA

e-mail: omarushc2@student.touro.edu are often vague, resulting in considerable variability in the management of early-stage melanoma among clinicians. The benefits of frequent follow-up visits are early detection of recurrent lesions, lower cost of early-stage melanoma compared to that of late-stage melanoma, decreased need for sentinel lymph node biopsy and adjuvant therapies, and the opportunity to educate patients on self-examination and sun protection. However, the high cost of screening and potential increased rates of biopsy, as well as over-imaging and overtreating, pose serious concerns about this approach. While more rigorous research is needed to resolve this controversy, currently clinicians should follow a relatively universal recommendation to tailor the follow-up regimen based on the patient's relative risk of recurrence and comfort.

Keywords: Early-stage melanoma; Follow-up guidelines; Management controversies 


\section{Key Summary Points}

Absence of universal guidelines for followup management in patients with earlystage melanoma may be a source of uncertainty among physicians and inconsistency in patient management.

Multiple advantages and disadvantages of different approaches should be addressed to come to a consensus.

A patient-centered plan that is based on individual risk factors and comfort is currently recommended.

The incidence of cutaneous melanoma continues to rise dramatically worldwide $[1,2]$. According to the National Cancer Institute, there will be over 100,000 new cases of cutaneous melanoma in the United States in 2020, continuing the trend of a constant increase over almost three decades [3]. Cohort studies in Europe demonstrate similar trends and indicate that a further increase in incidence rates is expected in the future [4]. Melanoma presents a considerable public health and a significant cost burden to the healthcare system, having the highest cost per death and the highest loss of productive life-years among all cancers in countries with high incidence [1, 2]. Despite this, there is still controversy in the guidelines regarding follow-up surveillance for patients with thin melanoma. Thin melanomas are those with a Breslow depth that ranges between 0.1 and $1.0 \mathrm{~mm}$ and represent approximately $70 \%$ of all new cases [5]. Treatment is surgical excision with a $1-\mathrm{cm}$ margin, while imaging is reserved only for symptomatic cases [6]. Sentinel lymph node biopsy should be discussed and considered for patients with T1b melanomas, which are those with either $0.8-1 \mathrm{~mm}$ depth or $<0.8 \mathrm{~mm}$ depth with ulceration [6]. The majority of these patients are managed exclusively by their general dermatologist [5]. Because of the limited number of randomized clinical trials to support evidence-based guidelines for follow-up surveillance, dermatologic and oncologic organizations have developed their own recommendations based on expert opinion [7].

Given the lack of evidence, skin cancer screening for the general population is not currently recommended by the United States Preventive Services Task Force [8]. For the higher-risk groups, which include those with a recent diagnosis of melanoma, leading physician organizations recommend routine skin surveillance, which includes a total-body skin examination, palpation of the primary site and surrounding area for recurrence and metastases, regional lymph node examination, and review of systems [1]. However, the guidelines published by these organizations (listed in Table 1) differ widely in the frequency of the in-office examinations and skin self-examinations as well as the longitudinal duration of the followup period. Moreover, even within each organization, guidelines range widely and are quite vague, resulting in considerable variability in the management of early-stage melanoma among clinicians [7]. The frequency of the follow-up visits ranges from 3 to 12 months. Most local recurrences or secondary melanomas appear within the first 3-5 years after the diagnosis, making an increased frequency during that period more appropriate $[1,6,9]$. A case series of patients with primary melanomas conducted at Duke University showed that about $40 \%$ of the patients had at least one recurrence, with the risk of recurrence peaking at 12 months and decreasing over time, but not reaching zero [10]. A large study by Leiter et al. revealed that about $40.5 \%$ of secondary melanomas were detected within the first year of the primary diagnosis, $54.4 \%$ within the first 2 years, and $25 \%$ after 5 years of follow-up [11]. However, late recurrence and secondary melanomas even more than 30 years after the primary diagnosis have been reported, especially in patients initially presenting with early-stage melanoma $[6,11]$. Thus, although there are no data directly supporting one schedule over another, and some authors question the cost efficiency of surveillance beyond 10 years, the majority of recommendations deem the lifelong 
Table 1 Guidelines for screening patients with cutaneous melanoma

\begin{tabular}{|c|c|c|c|}
\hline Organization & Stage & Office follow-up & Skin self-examination \\
\hline \multirow[t]{3}{*}{$\begin{array}{l}\text { American Academy of } \\
\text { Dermatology [9] }\end{array}$} & 0 & $\begin{array}{l}\text { At least every } 6-12 \text { months for } \\
1-2 \text { years; then annually }\end{array}$ & \multirow{3}{*}{$\begin{array}{l}\text { Self-examination of the skin and } \\
\text { lymph nodes for the detection of } \\
\text { recurrent disease or new melanoma } \\
\text { lesions is recommended }\end{array}$} \\
\hline & IA-IIA & $\begin{array}{l}\text { Every } 6-12 \text { months for } \\
2-5 \text { years; then at least } \\
\text { annually }\end{array}$ & \\
\hline & IIB-IV & $\begin{array}{l}\text { Every } 3-6 \text { months for } 2 \text { years; } \\
\text { then at least every } 6 \text { months } \\
\text { for } 3-5 \text { years; then at least } \\
\text { annually }\end{array}$ & \\
\hline \multirow[t]{4}{*}{$\begin{array}{l}\text { British Association of } \\
\text { Dermatologists [20] }\end{array}$} & 0 & $\begin{array}{l}\text { Follow-up exam after excision, } \\
\text { interval not specified }\end{array}$ & \multirow{4}{*}{$\begin{array}{l}\text { Self-examination for the detection of } \\
\text { recurrent disease or new melanoma } \\
\text { lesions is recommended }\end{array}$} \\
\hline & IA & $\begin{array}{l}\text { Every } 3-6 \text { months over up to } \\
1 \text { year }\end{array}$ & \\
\hline & IB-IIIA & $\begin{array}{l}\text { Every } 3 \text { months for } 3 \text { years; then } \\
\text { every } 6 \text { months for } 2 \text { years }\end{array}$ & \\
\hline & $\begin{array}{l}\text { IIIB-IV } \\
\quad \text { (resected) }\end{array}$ & $\begin{array}{l}\text { Every } 3 \text { months for } 3 \text { years; then } \\
\text { every } 6 \text { months for } 2 \text { years; } \\
\text { then annually for } 5 \text { years }\end{array}$ & \\
\hline $\begin{array}{l}\text { Clinical Practice Guidelines for } \\
\text { the Management of Melanoma } \\
\text { in Australia and New Zealand } \\
\text { [21] }\end{array}$ & $\begin{array}{l}\text { I } \\
\text { II-III }\end{array}$ & $\begin{array}{l}\text { Every } 6 \text { months for } 5 \text { years } \\
\text { Every } 3-4 \text { months for } 5 \text { years; } \\
\text { then annually }\end{array}$ & $\begin{array}{l}\text { Self-examination by patients is } \\
\text { essential }\end{array}$ \\
\hline \multirow{3}{*}{$\begin{array}{l}\text { National Comprehensive Cancer } \\
\text { Network [6] }\end{array}$} & 0 & At least annually & \multirow{3}{*}{$\begin{array}{l}\text { Regular post-treatment self- } \\
\text { examination of the skin and lymph } \\
\text { nodes is recommended }\end{array}$} \\
\hline & IA-IIA & $\begin{array}{l}\text { Every } 6-12 \text { months for } 5 \text { years; } \\
\text { then annually }\end{array}$ & \\
\hline & IIB-IV & $\begin{array}{l}\text { Every } 3-6 \text { months for } 2 \text { years; } \\
\text { then every } 3-12 \text { months for } \\
3 \text { years; then annually }\end{array}$ & \\
\hline
\end{tabular}

follow-up to be justified due to increased risk of recurrence $[6,9]$.

As with any medical intervention, there are advantages and disadvantages to increased skin surveillance. Gardner et al. analyzed the published works that support multiple benefits of screening, dividing them into a few categories. First of all, multiple case-control studies showed that frequent skin examinations resulted in earlier melanoma detection [8]. Because lesions are thinner and more manageable, patients with melanoma diagnosed at an early stage have significantly lower mortality and morbidity [1]. Furthermore, surveillance and treatment of early-stage melanoma is significantly less costly than that for advancedstage melanoma, since thinner melanomas are less likely to require sentinel lymph node biopsy 
and adjuvant therapies. A melanoma expense model comparing the overall costs of various stages of melanoma estimated that treatment of a T4b melanoma lesion was about 20 times as expensive as melanoma in situ and ten times as expensive as T1a lesion treatment [8]. Additionally, follow-ups present an opportunity to educate patients on self-examination and sun protection, as well as to identify family members who might be at increased risk and provide ongoing psychosocial support $[6,8,9]$.

There are still costs to increased skin surveillance that have to be balanced by those advantages. While earlier-stage diagnosis offers significant cost savings on treatment mentioned above, the cost-effectiveness of screening is a major factor in forming guidelines. A study conducted at the University of Pittsburgh Medical Center estimated a cost of $\$ 32,594$ to detect a single melanoma lesion [12]. According to one screening trial, 620 people needed to be screened to find one melanoma, whereas other studies showed that the number of biopsies needed to diagnose one melanoma ranged from 50 to 100 $[8,13]$. Another factor against an intense followup regimen is the likely increase in biopsy rates, as well as potential for overdiagnosis and overtreatment, which may or may not end up reducing mortality [8]. Moreover, increased biopsy rates may lead to unnecessary re-excisions, which can cause additional cosmetic, psychological, and functional morbidity [8].

There is no doubt that more rigorous research is needed to resolve these issues. Meanwhile, how should clinicians manage the follow-up for their patients with thin melanomas? A relatively universal recommendation is to tailor the follow-up regimen to the relative risk of recurrence [6-9]. Risk factors presented in guidelines include multiple primary melanomas, familial melanoma with first melanoma diagnosed before 40 years of age, family history of melanoma, documented genetic predisposition to melanoma, personal history of nonmelanoma skin cancer, immunosuppression, and physical features associated with increased risk (blond or red hair, more than 40 nevi, more than two clinically atypical nevi, freckling, and other signs of ultraviolet radiation overexposure) [6-9]. The follow-up surveillance can also be modified in accordance with the perceived difficulty of examination: patients with numerous atypical nevi may be monitored by photography or digital dermoscopy, and patients not able to routinely perform skin selfexamination may benefit from more frequent office visits [7]. Lastly, the importance of patient education on thorough skin self-examination should not be underestimated. Multiple studies have shown that about $50 \%$ to $62 \%$ of patients detect recurrent lesions between office visits [2, 7, 14-17]. In Australia, where melanoma prevention and awareness have been receiving active promotion, the number was even higher, at about $75 \%$ of patients [10]. Some studies suggest that due to such a high rate of self-detection, it is reasonable to favor a less intense inoffice surveillance regimen and to focus more on skin self-examination, as it could both significantly reduce the financial burden and save physicians time, allowing for more efficient distribution of resources in the healthcare system $[18,19]$. On the other hand, a significant proportion of patients who detect malignant lesions seek evaluation by a professional with delays, consequently presenting with increased tumor thickness, resulting in poorer patient outcomes $[2,14]$. Thus, skin self-examination is a cost-effective and essential supplement to the in-office examination, which should be approached with caution and understanding that patients' ability to detect malignant lesions may vary greatly and requires sufficient patient education by the healthcare provider and active secondary skin cancer prevention campaigns to promote population awareness [2, 10].

Currently, given the limited number of randomized controlled trials on this matter, management of early-stage melanomas will likely vary from patient to patient. A patient-centered plan that is based on their individual risk factors and comfort is recommended and relies heavily on the clinicians' level of expertise and professional judgment. As we learn more about the specific factors that contribute to mortality in those with thin melanomas, we look forward to more specific and consistent guidelines with regard to patient management and follow-up, which will account for the long-term effect on quality of life, survival, and cost-effectiveness. 


\section{DIGITAL FEATURES}

This article is published with digital features to facilitate understanding of the article. To view digital features for this article go to https://doi. org/10.6084/m9.figshare.12911654.

\section{ACKNOWLEDGEMENTS}

Funding. No funding or sponsorship was received for this study or publication of this article.

Authorship. All named authors meet the International Committee of Medical Journal Editors (ICMJE) criteria for authorship for this article, take responsibility for the integrity of the work as a whole, and have given their approval for this version to be published.

Authorship Contributions. Each named author has contributed substantially to conducting the research and drafting this manuscript.

Disclosures. All authors (Olga Marushchak, Ezra Hazan, and David A. Kriegel) have nothing to disclose.

Compliance with Ethics Guidelines. This article is based on previously conducted studies and does not contain any studies with human participants or animals performed by any of the authors.

Data Availability. Data sharing is not applicable to this article as no data sets were generated or analyzed during the current study.

Open Access. This article is licensed under a Creative Commons Attribution-NonCommercial 4.0 International License, which permits any non-commercial use, sharing, adaptation, distribution and reproduction in any medium or format, as long as you give appropriate credit to the original author(s) and the source, provide a link to the Creative Commons licence, and indicate if changes were made. The images or other third party material in this article are included in the article's Creative Commons licence, unless indicated otherwise in a credit line to the material. If material is not included in the article's Creative Commons licence and your intended use is not permitted by statutory regulation or exceeds the permitted use, you will need to obtain permission directly from the copyright holder. To view a copy of this licence, visit http:// creativecommons.org/licenses/by-nc/4.0/.

\section{REFERENCES}

1. Ward WH, Farma JM. Cutaneous Melanoma: Etiology and Therapy. Brisbane (AU): Codon Publications; 2017. https://www.ncbi.nlm.nih.gov/books/ NBK481860/https://doi.org/10.15586/codon. cutaneousmelanoma.2017. Accessed 30 April 2020.

2. Avilés-Izquierdo JA, Molina-López I, RodríguezLomba E, Marquez-Rodas I, Suarez-Fernandez R, Lazaro-Ochaita P. Who detects melanoma? Impact of detection patterns on characteristics and prognosis of patients with melanoma. J Am Acad Dermatol. 2016;75(5):967-74. https://doi.org/10.1016/ j.jaad.2016.07.009.

3. National Cancer Institute. Surveillance, Epidemiology, and End Results Program website. Cancer stat facts: melanoma of the skin. 2020. https://seer. cancer.gov/statfacts/html/melan.html. Accessed 29 April 2020.

4. Garbe C, Leiter U. Melanoma epidemiology and trends. Clin Dermatol. 2009;27:3-9. https://doi. org/10.1016/j.clindermatol.2008.09.001.

5. Chiaravalloti AJ, Jinna S, Kerr PE, Whalen J, GrantKels JM. A deep look into thin melanomas: what's new for the clinician and the impact on the patient. Int J Womens Dermatol. 2018;4(3):119-21. https:// doi.org/10.1016/j.ijwd.2018.01.003.

6. Coit DG, Thompson JA, Albertini MR, et al. Cutaneous Melanoma, Version 1.2020, NCCN Clinical Practice Guidelines in Oncology. National Comprehensive Cancer Network. 2019. https://www. nccn.org/professionals/physician_gls/default. aspx\#melanoma. Accessed 6 January 2020.

7. Klapperich ME, Bowen GM, Grossman D. Current controversies in early-stage melanoma: questions on management and surveillance. J Am Acad Dermatol. 2019;80(1):15-25. https://doi.org/10.1016/j. jaad.2018.03.054. 
8. Gardner LJ, Strunck JL, Wu YP, Grossman D. Current controversies in early-stage melanoma: questions on incidence, screening, and histologic regression. J Am Acad Dermatol. 2019;80(1):1-12. https://doi.org/10.1016/j.jaad.2018.03.053.

9. Swetter SM, Tsao H, Bichakjian CK, et al. Guidelines of care for the management of primary cutaneous melanoma. J Am Acad Dermatol. 2019;80(1): 208-50. https://doi.org/10.1016/j.jaad.2018.08. 055 .

10. Barbour AA, Guminski A, Liu W, Menzies S, Morton R. Cancer Council Australia Melanoma Guidelines Working Party. What is the ideal setting, duration and frequency of follow-up for melanoma patients? https://wiki.cancer.org.au/australia/Guidelines: Melanoma. Accessed 26 Aug 2020.

11. Leiter U, Buettner PG, Eigentler TK, et al. Hazard rates for recurrent and secondary cutaneous melanoma: an analysis of 33,384 patients in the German Central Malignant Melanoma Registry. J Am Acad Dermatol. 2012;66(1):37-45. https://doi.org/10. 1016/j.jaad.2010.09.772.

12. Matsumoto M, Secrest A, Anderson A, et al. Estimating the cost of skin cancer detection by dermatology providers in a large health care system. J Am Acad Dermatol. 2018;78(4):701-9. https://doi. org/10.1016/j.jaad.2017.11.033.

13. Waldmann A, Nolte S, Geller AC, et al. Frequency of excisions and yields of malignant skin tumors in a population-based screening intervention of 360,288 whole-body examinations. Arch Dermatol. 2012;148:903-10. archdermatol.2012.893.

14. Chao L, Patterson S, Rademaker A, Liu D, Kundu R. Melanoma perception in people of color: a targeted educational intervention. Am J Clin Dermatol. 2017;18(3):419-27. s40257-016-0244-y.
15. McGuire ST, Secrest AM, Andrulonis R, Ferris LK. Surveillance of patients for early detection of melanoma: patterns in dermatologist vs patient discovery. Arch Dermatol. 2011;147(6):673-8. https:// doi.org/10.1001/archdermatol.2011.135.

16. Francken AB, Bastiaannet E, Hoekstra HJ. Follow-up in patients with localised primary cutaneous melanoma. Lancet Oncol. 2005;6(8):608-21. https://doi. org/10.1016/S1470-2045(05)70283-7.

17. Francken AB, Shaw HM, Accortt NA, Soong SJ, Hoekstra HJ, Thompson JF. Detection of first relapse in cutaneous melanoma patients: implications for the formulation of evidence-based follow-up guidelines. Ann Surg Oncol. 2007;14(6):1924-33. https://doi.org/10.1245/s10434-007-9347-2.

18. Deckers EA, Hoekstra-Weebers JEHM, Damude S, et al. The MELFO study: a multicenter, prospective, randomized clinical trial on the effects of a reduced stage-adjusted follow-up schedule on cutaneous melanoma IB-IIC patients-results After 3 Years. Ann Surg Oncol. 2020;27(5):1407-17. https://doi.org/ 10.1245/s10434-019-07825-7.

19. Murchie P, Nicolson MC, Hannaford PC, Raja EA, Lee AJ, Campbell NC. Patient satisfaction with GPled melanoma follow-up: a randomised controlled trial. Br J Cancer. 2010;102(10):1447-555. https:// doi.org/10.1038/sj.bjc.6605638.

20. Marsden JR, Newton-Bishop JA, Burrows L, et al. Revised U.K. guidelines for the management of cutaneous melanoma 2010. Brit J Dermatol. 2010;163(2):238-56. https://doi.org/10.1111/j. 1365-2133.2010.09883.x.

21. Clinical Practice Guidelines for the Management of Melanoma in Australia and New Zealand. Wellington, New Zealand: New Zealand Guidelines Group; 2008. https://www.health.govt.nz/system/files/ documents/publications/melanoma-guidelinenov08-v2.pdf. Accessed 1 February 2020. 